\title{
'What Gets Measured Gets Done': Exploring the Social Construction of Globalized Knowledge for Development
}

Ruth Buchanan

Osgoode Hall Law School of York University, rbuchanan@osgoode.yorku.ca

Kimberley Byers

Kristina Mansveld

\section{Source Publication:}

Research Handbook on the Sociology of International Law by Moshe Hirsche and Andrew Lang (eds.), Cheltenham, UK and Northampton, MA, USA: Edward Elgar, 2018, pp. 101-121.

Follow this and additional works at: https://digitalcommons.osgoode.yorku.ca/scholarly_works

Part of the Law Commons

\section{Repository Citation}

Buchanan, Ruth; Byers, Kimberley; and Mansveld, Kristina, "'What Gets Measured Gets Done': Exploring the Social Construction of Globalized Knowledge for Development" (2018). Articles \& Book Chapters. 2624. https://digitalcommons.osgoode.yorku.ca/scholarly_works/2624 


\title{
'What gets measured gets done': exploring the social construction of globalized knowledge for development
}

\author{
Ruth Buchanan, Kimberley Byers and Kristina Mansveld
}

\begin{abstract}
The project of international development can be understood as a way of seeing the world that is both constituted by and interwoven with evolving processes of measurement, comparison and quantification. Drawing on the sociological insight that regimes of measurement can never be 'neutral' representations of external 'objects', but are instead actively engaged in shaping what can be known, this chapter critically examines the ways in which the production of globalized rankings and metrics are imbricated with the production of the social and economic hierarchies that development as a project seeks to ameliorate. The chapter illustrates the mechanisms and effects of this co-production of the development project and its practices of quantification, through a close consideration of the case of Millennium Development Goal 7 Target D.
\end{abstract}

'What we know about the world is intimately linked to our sense of what can we can do about it, as well as to the felt legitimacy of specific actors, instruments and courses of action. "l

'What gets measured gets done.' - MDG Final Report, 2015

\section{A. Introduction}

The project of international development can be understood as a way of seeing the world that is both constituted by and interwoven with evolving processes of measurement, comparison and quantification. What development is understood to be and how it is measured are mutually constitutive processes. Development emerges as a way of locating 'underdeveloped' states in relation to the rich world after the Second World War. ${ }^{2}$ Since the postwar era, the definition and objectives of development have evolved in tandem with available data sets. ${ }^{3}$ Drawing on the sociological

\footnotetext{
${ }^{1}$ Sheila Jasanoff, 'Ordering Knowledge, Ordering Society' in Sheila Jasanoff (ed), States of Knowledge: The Co-Production of Science and Social Order (Routledge 2004) 14.

${ }^{2}$ Sundhya Pahuja, Decolonizing International Law: Development, Economic Growth and the Politics of Universality (CUP 2011).

${ }^{3}$ E Wayne Nafziger, 'From Seers to Sen: The Meaning of Economic Development' in George Mavrotas and Anthony Shorrocks (eds), Advancing
} 
insight that regimes of measurement can never be 'neutral' representations of external 'objects', but are instead actively engaged in shaping what can be known, this chapter approaches the various rankings and metrics created by development institutions as practices that are both integral to and constitutive of the project of development.

The proliferation of international development indices over the past several decades has made knowledge production for development an important arena of inquiry for socio-legal scholars interested in international institutions and governance. ${ }^{4} \mathrm{~A}$ considerable amount of research has been conducted on the mechanisms by which credibility and influence over development policy are acquired through the production and dissemination of quantified and commensurable data sets. ${ }^{5}$ We know, for example, that the reliance upon quantitative and measurable targets are favoured by international institutions such as the World Bank, possessing the financial and professional resources to create and monitor the necessary knowledge collection infrastructures. ${ }^{6}$ The imperative to produce tangible measures of development outcomes is usually rationalized in terms of benefits, such as the ability to focus on particular issues, increased accountability, and improved policies. And yet it is also well established that these practices of quantification are 'bound up in entanglements of power' and can work to inscribe hierarchies. ${ }^{7}$ Research has documented the variety of productive effects, both intended and unintended, that are bound up with indicators' growing significance as a technology of governance, including their key role in shaping 'what can be known at any given time, as well as how that knowledge can be

Development (Palgrave Macmillan 2007) 50. See also Dudley Seers, 'The Meaning of Development' (1969) IDS Communication 44, Institute of Development Studies.

${ }^{4}$ Kevin E Davis et al., Governance by Indicators: Global Power through Classification and Rankings (OUP 2012); Kevin E Davis and Benedict Kingsbury, 'Indicators as Interventions: Pitfalls and Prospects in Supporting Development Initiatives' (Report, Rockefeller Foundation 2011); Doris Buss, 'Measurement Imperatives and Gender Politics: An Introduction' (2015) 22(3) Social Politics $381<$ http://doi.org/10.1093/sp/jxv030>.

${ }^{5}$ Richard Rottenburg et al. (eds), The World of Indicators: The Making of Governmental Knowledge through Quantification (CUP 2015).

${ }^{6}$ David Kennedy, A World of Struggle: How Power, Law, and Expertise Shape Global Political Economy (1st edn, Princeton University Press 2016).

${ }^{7}$ Buss (n 4); Tor Krever, 'Quantifying Law: Legal Indicator Projects and the Reproduction of Neoliberal Common Sense' (2013) 34(1) Third World Q 131; Amanda Perry-Kessaris, 'Prepare Your Indicators: Economics Imperialism on the Shores of Law and Development' (2011) 7(4) Int J Law Context 401 <http://doi.org/doi:10.1017/S174455231100022X>. 
used.' ${ }^{8}$ Yamin and Fukuda Parr have noted, in relation to the Millennium Development Goals, that they had the capacity to 'redefine the framework for understanding the purpose of development, the key constraints and the means to address them." 9 Development indices determine which information counts, and which doesn't, for the purpose of identifying desirable development outcomes and orienting future development policy.

As measures of development have proliferated, so have debates over the appropriateness or suitability of competing measurement regimes. Tracking development outcomes is a complex social process that involves a series of evaluative decisions, including what is to be the target of measurement, which indicators will be chosen to stand as proxies for the target, and which institutions or practices will be utilized for measuring, compiling, and tracking. These decisions all matter a great deal to the intended beneficiaries of development policies - poor states and their citizens - and yet their role in these processes of knowledge production is, for the most part, passive and limited. The 'power of numbers' used in this way lies in the process by which these difficult and contestable choices become submerged, or 'blackboxed' in the ensuing indicator, such that the resulting 'data' appear straightforward and 'factual'. ${ }^{10}$ Moreover, that some 'objects' (income poverty, maternal mortality) seem inherently 'measurable' while others (community empowerment, tenure security) seem to resist measurement is itself an effect of an already existing 'information infrastructure that has 'preformatted' categories, data, and concepts in order to render them countable.' ${ }^{11}$ While some commentators have identified in the emergence of various 'alternative' indices the potential for contestation, it is also clear that the most powerful and effective indicators are those that globally commensurate-that is, they function to dis-embed data from local contexts, facilitating crossnational comparisons. To the extent that alternative indices seek to re-embed salient local factors, or to revalorize overlooked concerns, they encounter what Merry and Wood have described as the 'paradox of measurement'; that is, 'indicators reveal

\footnotetext{
${ }^{8}$ Buss, ibid. 3. See also Mary Poovey, A History of the Modern Fact: Problems of Knowledge in the Sciences of Wealth and Society (1st edn, University Of Chicago Press 1998) 7.

${ }^{9}$ Sakiko Fukuda-Parr and Alicia Ely Yamin, 'The Power of Numbers: A Critical Review of MDG Targets and Indicators' (2013) 56(1) Development 58, 59.

10 Tony Porter, 'Making Serious Measures: Numerical Indices, Peer Review, and Transnational Actor-Networks' (2012) 15(4) J INT RELAT DEV 532 <http://doi.org/doi:10.1057/jird.2011.15>.

11 Nehal Bhuta comment on Sally Engle Merry and Summer Wood, 'Quantification and the Paradox of Measurement: Translating Children's Rights in Tanzania' (2015) 56(2) Curr Anthropol 205, 219.
} 
information about issues that are already being measured well, but they do not shed light on important problems that are not being measured.' 12

If development indicators are understood in this way - as part of a thickening swarm of technologies of quantified knowledge production and data circulating on a global scale -they present a different sort of challenge to the researcher. In the place of familiar debates over the adequacy and accuracy of data and the selection of appropriate indicators, a different and more salient question emerges: whether and in what ways development indicators function to constitute and maintain the global inequalities that the development project is charged with dismantling. ${ }^{13}$ This chapter seeks both to encapsulate this methodological reorientation with reference to the burgeoning literature on indicators and development, as well as to provide one cogent illustration of the process of co-evolution in the definition and measurement of development outcomes through a brief account of MDG 7D.

As we detail below, the 'slum' - as a way of both seeing and measuring urban poverty - was explicitly drawn into international development discourse through a Cities Alliance Report entitled 'Cities without Slums', from which the Millennium Declaration drew its modest objective. This objective was subsequently incorporated into Millennium Development Goal \#7, on sustainable development, which included as one of its targets; 'to bring about, by 2020 significant improvements in the lives of at least 100 million slum-dwellers'. Through the high level endorsement of the MDG's by international institutions, this target, also known as the Cities without Slums target, quickly became a highly influential mechanism for the production of knowledge for urban development, notwithstanding numerous challenges associated with its definition and tracking. The successful achievement of this modest target was announced well before the conclusion of the MDG project in 2015. However, the MDG Final Report also noted that between 2000 and 2015, the absolute number of slum-dwellers globally had increased by 88 million to an estimated total of 880 million between 2000 and 2015. During the same timeframe, a series of UN Habitat Reports documented the ongoing problem of wide-scale summary evictions of urban slum-dwellers. These data suggest that the 'success' of the target in achieving its overall objective of 'improving the lives of slumdwellers' is at the very least debatable, and that a closer examination of the relationship between goals and metrics is called

\footnotetext{
${ }^{12}$ Ibid. 212.

${ }^{13}$ See generally Ian Hacking, The Social Construction of What? (ch 2, Harvard University Press 2000).
} 
for. In this chapter, we are most interested in what new forms of knowledge are being produced and put into circulation by the international community's decision to 'target slums'.

The chapter proceeds as follows. The first section situates the development project, locating its origins in a historical moment that gave rise both to a new type of knowledge about national economies and a way of distinguishing between those economies that are 'underdeveloped' and those that are developed. In the second section, we provide a snapshot of the scholarship on expert knowledge as a world-making practice and, in particular, the extensive literature on measurement, quantification, and indicators that has emerged in the past two decades. From these broad debates, we draw out insights specifically relating to the sociology of knowledge construction for development, in order to begin to frame a critical sociological approach to development indicators. Finally, we illustrate how one might approach a specific development indicator in this way through a brief description of the formulation and implementation of Millennium Development Goal 7.D (the Cities without Slums target).

B. What is development?

'Development ... is a specific way of knowing the world, which is both discourse and institutional machinery.' ${ }^{14}$

Although it claims to offer pathways to the realization of universal human aspirations for wellbeing, flourishing, or human freedom, 'development' is understood here as a particular (western) project that incorporates both a way of seeing the world as well as a process of initiation or enculturation into that way of seeing. This two-part definition is echoed by Gilbert Rist, for whom development can be understood as 'a belief and a series of practices which form a single whole in spite of contradictions between them. ${ }^{15}$ The world-making effects of development take shape, largely, through the work of international institutions and the 'development' projects that they support. It is through the practices, reports, and statistics generated by these multilateral institutions and agencies, so frequently located in the west and

${ }^{14}$ Sundhya Pahjua, 'Poverty and the Politics of Good Intentions' in Ruth Buchanan and Peer Zumbansen (eds), Law in Transition: Human Rights, Development and Transitional Justice (Hart Publishing, 2014) 35. 'Development has a very particular history, which is both a legacy of imperialism and intimately intertwined with the history of contemporary international law. It is not just a word; it is a specific way of knowing the world, which is both discourse and institutional machinery.'

${ }^{15}$ Gilbert Rist, The History of Development: From Western Origins to Global Faith (Zed Books, 2002) 24. 
headed up by westerners, that the particular ideals and aspirations of the west are projected onto the rest of the world in the guise of development as a universal good. This chapter approaches this relation as an always in-process co-production, such that at any given time, it is not possible to ask the question 'what is development' without at the same time asking 'how is it measured'?

In orienting an account of the development project as a specific way of looking at the rest (of the world) by the west, there are multiple available starting-points, including many that mine the writings of early jurists to trace continuities between colonial and post-colonial eras. ${ }^{16}$ For our purpose in this chapter, however, of particular relevance is the emergence of an idea and practice of development in the post-war/Bretton Woods era. In this context, President Truman's inaugural address of January 1949 is a helpful, albeit much remarked upon, keystone. Truman's fourth point has been identified as one of the first instances in which the word 'underdevelopment' makes its way into public discourse as a term used to refer collectively to parts of the globe that had not, at that time, industrialized. ${ }^{17}$ What is of critical interest to us in this chapter, however, is the way in which, in Truman's fourth point, that idea of 'development' is fused to a technology of measurement, which in our account is critical to its emergence as a powerful world-making assemblage.

The technology of measurement is, of course, economic growth, as determined by emergent measures of Gross National Product. Truman's speech took place at a pivotal moment in the emergence of the idea of a 'national economy,' dependent on new methods of tracking and accounting for wealth developed by the emerging field of economics and exemplified best by the measure of GNP as a proxy for the economic output of an entire nation, first developed in the US by economist Simon Kuznets. ${ }^{18}$ Kuznets's work at the U.S. National Bureau of Economic Research in the

${ }^{16}$ The writings of jurists such as Franciso de Vitoria, Frederick Lugard, and Henry Maine have all provided grist for this mill. See also Antony Anghie, Imperialism, Sovereignty, and the Making of International Law (Cambridge University Press 2005); Amanda Perry-Kessaris, 'The Case for a Visualized Economic Sociology of Legal Development' (2014) 67(1) Curr Leg Probl 169 <http://doi.org/doi:10.1093/clp/cuu016>.

${ }^{17}$ Rist (n 15); Luis Eslava, Local Space, Global Life: The Everyday Operation of International Law and Development (CUP 2015); Pahuja (n 2 60-62); Jennifer Beard, The Political Economy of Desire: Law Development and the Nation (GlassHouse, 2005); and many others have offered up particularly useful analyses of Truman's address.

18 Timothy Mitchell, Carbon Democracy: Political Power in the Age of Oil (Verso Books 2011) 136ff. In relation to GNP, Mitchell cites Kuznets's warning that 'a national total facilitates the ascription of independent significance to that vague entity called the national economy' (137) which clearly went unheeded. 
1930s had attracted the interest of policy-makers and led to a series of conferences on conceptual and methodological issues relating to macro-economic measures, at which the term Gross National Product was first introduced as a macro-measure of economic output. ${ }^{19}$ During the Second World War, Kuznets effectively applied that data collection and statistical modelling work on national income growth in support of the U.S. war effort. ${ }^{20}$ In the postwar era, the tracking of GNP growth became the 'dominant metric of economic performance across the western world', and an international approach to standardized national accounting based very closely on Kuznets's methodology was adopted by the UN by $1953 .{ }^{21}$ Notwithstanding warnings by Kuznets and others about the limitations of the methodology, neoclassical growth theory emerged as the new mainstream approach to economics, and GNP (later GDP) became the ultimate proxy for national welfare. ${ }^{22}$ Timothy Mitchell underscores the 'world-making' aspect of these developments, noting the extent to which the 'calculative machinery' of economics became imbricated with the world that it was purporting to merely measure:

These transformations created in the twentieth century a political and material world densely imbued with the expertise, calculative techniques and conceptual machinery of modern economics. The so-called material world of governments, corporations, consumers and objects of consumption was arranged, managed, formatted and run with the help of economic expertise. The readiness with which it seemed that this world could be manipulated and modeled by economics reflected not simply that it was a naturally 'quantitative' world, as Schumpeter suggested. It reflected the imbrication of the concepts and calculations of economic science in the world it was studying. ${ }^{23}$

In Truman's fourth point, these two key transformations of the mid-twentieth-century are fused together. In his promise 'to make scientific advances and industrial progress available for the improvement and growth of underdeveloped areas', Truman defined the development project as a project of economic growth (understood in terms of GNP). ${ }^{24}$ In this way, the distinction between 'underdeveloped' and 'developed' parts of the world and the identification of the technical expertise for measuring progress with the discipline of economics were brought together. The

19 Lorenzo Fioramonti, Gross Domestic Problem: The Politics Behind the World's Most Powerful Number (Zed Books 2013) 26-27.

${ }^{20}$ Ibid. 31-32.

${ }^{21}$ Ibid. 32.

${ }^{22}$ Ibid. 51.

${ }^{23}$ Mitchell (n 18) 139.

${ }^{24}$ Pahuja (n 2) 64-65. 
outcome of this fusion is a reframing of the 'old' imperial hierarchies into a 'modern' hierarchy determined not by power relations but by economics. ${ }^{25}$ As noted above, GNP was still a relatively novel and limited aggregative measure of national economic activity in 1949; Truman's speech arguably facilitates the transformation of Kuznets's method for estimating levels of domestic economic activity in the US into a figure used for the measurement and comparison of economic activity among developing states, and between developing and developed states. ${ }^{26}$

Notwithstanding the evident limitations of using a figure that measures only 'marketized' economic activity to calculate and compare productive activity across economies with widely varying degrees of 'marketization', and in spite of critiques by Kuznets and others that drew attention to its inaccuracies and inadequacies, GNP growth quickly transmogrified into both the 'objective and yardstick of development.' ${ }^{27}$ That this alchemy so soon became unremarkable exposes the constitutive or 'world-making' nature of the development project that emerged in the postwar moment. Truman's speech illustrates that the project of international 'development' is conceived fundamentally as a project of measurement, comparison, and quantification. Moreover, it reveals the manner in which, from the outset, a perspective is embedded from which it appears possible to 'see' a national economy as a totality and to measure its successes and failures in aggregative terms.

The apparent success of GNP as a way of 'seeing' an economy should not be equated with an absence of struggle, however. As David Kennedy has cogently argued, contestation among experts over the best ways to measure and compare economies, governance, growth, poverty, well-being, or human rights are a defining feature of our globalized social order. ${ }^{28}$ Debates over how to measure development have been in existence as long as debates over the nature of development itself. As early as 1969, in a foundational article 'The Meaning of Development', Dudley Seers observed that international 'development' as it was

\footnotetext{
${ }^{25}$ Ibid. 64. As Pahuja explains: 'the specific way in which development rejected race-based distinctions without challenging hierarchical organization or foreign domination per se was to eschew the now dubious value claims of imperialism and the newly discredited idea of racial superiority and to replace them with the 'scientific' measure of GNP.'

${ }^{26}$ Rist puts it more directly: 'Point Four simply imposed a new standard whereby the United States stood at the top: namely, the Gross Domestic Product'. Rist (n 15) 76.

${ }^{27}$ Erik Thorbecke, 'The Evolution of the Development Doctrine, 1950-2005' in George Mavrotas and Anthony Shorrocks (eds), Advancing Development: Core Themes in Global Economics (Palgrave MacMillan 2007) 5.

${ }^{28}$ Kennedy (n 6).
} 
conceived and took shape in the postwar era was fundamentally a project that operated through mechanisms of quantification that were largely inadequate to the task. ${ }^{29}$ Seers was an early critic of GDP as a measure of development; but he was not alone for long. Indeed, development critics proliferated, and by the early 1990s, the work of Amartya Sen on capabilities, along with a dramatic increase in available statistics, facilitated the creation of the Human Development Index, tied to the UNDP's Human Development Reports as an alternative framework for approaching the work of development. ${ }^{30}$ The Human Development Reports, in particular, sought to track a wider range of factors considered relevant to the well-being of populations. The HDI generated its own debates, which led in turn to the creation of several additional indices. ${ }^{31}$ In turn, and as we elaborate below, the Millennium Development Goals were added to the mix, and new controversies emerged over the identification of targets and indicators, how they would be tracked, and which measures - and hence whose issues were to be given priority. At the time of writing, nearly sixty-eight years have elapsed since Truman's inaugural address, and what can be observed of the intervening period is that while the measures of development have proliferated, and competition between measures has intensified, the fundamental connection between development and indicators of development has remained in place.

\section{Towards a critical sociology of development indicators}

Measurement is never an innocent act. It is a thoroughly social process, from the array of individuals and communities engaged in the act of generating data, to the effects on the social relationships and institutions that are the subjects of measurement. Categories of people and behavior are created to enable counting, comparison and ranking to take place, affecting how problems are defined and emerge as worthy of attention. ${ }^{32}$

Sidestepping the longstanding debates within development studies over the sufficiency or suitability of various indicators, this chapter, rather, is located within a different body of scholarship that seeks to examine the ways in which quantification, and concomitant processes such as the production and tracking of indicators, operate as mechanisms of knowledge production. ${ }^{33}$ As governments, firms, and intergovernmental organizations have

\footnotetext{
${ }^{29}$ Seers (n 3)..

${ }^{30}$ Nafziger (n 3).

${ }^{31}$ Elizabeth A Stanton, 'The Human Development Index: A History' (2007) 127 PERI Working Papers <http://scholarworks.umass.edu/peri_workingpapers/85>.

${ }^{32}$ Buss (n 4) 1.

${ }^{33}$ Jasanoff (n 1); Poovey (n 8).
} 
continued to expand the scope and complexity of data that they gather and use for a variety of purposes, the study of quantification, measurement and indicators has become an increasingly significant (and crowded) field of scholarly interest. ${ }^{34}$ Some of this work draws inspiration from (interdisciplinary) science and technology studies, including the work of Jasanoff, Callon, and Latour. Other contributions are more disciplinarily rooted in the fields and methods of anthropology, sociology, or history. ${ }^{35}$ In keeping with the mandate of the volume, this chapter seeks to bring into focus what a sociological orientation to the study of indicators and development might contribute to these debates. To this end, we draw on the work of Espeland and Stevens, who have provided a general framework for engaging in the sociological analysis of the constitutive effects of social processes of quantification, such those carried out under the rubric of development. In particular, Espeland and Stevens have identified five distinct mechanisms through which quantification achieves its social effects. In this section, we will illustrate each of these mechanisms - 'work', 'reactivity', 'discipline', 'polyvalent authority' and 'aesthetics', using examples from the burgeoning scholarship on development indicators.

The first mechanism that Espeland and Stevens identify in their methodological framework for the social study of quantification is 'work'. In their analysis, 'work' refers to the necessary infrastructure that lies behind the generation of numbers. It draws our attention to the processes by which the concepts and categories for counting must be invented, and the mechanisms for collecting and compiling the data that must be developed. Once gathered and analysed, this new information will need to be formatted and circulated to potential audiences, requiring considerable investments of time and energy by people and institutions, and yet, 'we often forget how much infrastructure lies behind the numbers that are the end product of counting regimes.' ${ }^{36}$ Indeed, it is a frequently remarked upon feature of successful measurement formats that the considerable amount of work 'behind' the numbers becomes invisible. What is seen as 'natural' and even 'value neutral' are the products of that work-

\footnotetext{
${ }^{34}$ Recent contributions to this field are diverse and they are numerous. Notable among them are: Fukuda-Parr and Yamin (n 9); Kevin E Davis et al., 'Introduction: Global Governance by Indicators' in Governance by Indicators: Global Power through Classification and Rankings, Kevin Davis et al. (eds), (OUP 2012); Merry and Wood (n 11); Krever (n 7).

${ }^{35}$ Sally Engle Merry and Susan Bibler Coutin, 'Technologies of Truth in the Anthropology of Conflict: AES/APLA Presidential Address, 2013' (2014) 41(1) Am Ethnol $1<$ http://dx.doi.org/doi:10.1111/amet.12055>.

36 Wendy Nelson Espeland and Mitchell L Stevens, 'A Sociology of Quantification' (2008) 49(3) Eur. J. Soc. Theory 401, 411.
} 
categories of people and things, that they are seeking to measure, along with the data that are gathered about these categories. So, Yamin and Fukuda Parr note in relation to the MDG's that 'once these numerical targets were set, they were perceived to be value neutral. In fact, however, there were assumptions deeply embedded in the MDG's about the nature and purpose of development. ${ }^{37}$ Scholars of quantification who work within the STS vocabulary might describe this as a process of 'black boxing' - once the foundational controversies over a particular measurement are settled, 'the objects they produce can travel through networks without their foundational controversies being questioned or visible'. ${ }^{38}$

Attending to the work of quantification also allows us to observe that the necessary institutional infrastructure is unequally distributed in our world, and perhaps enables or even enjoins us to attend more closely to what this unevenness might throw up. As we described in the first section, the 'development project' as it emerged in the postwar era was fundamentally a project of measurement and comparison. Given that it is impossible to track and compare what is not being counted, the lack of statistical capacity in many poor countries becomes transformed into a key development issue, and competes for funding with other worthy projects addressing access to education, water and sanitation, or adequate health care. The need for statistical capacity building in poor countries became a key plank in the poverty reduction strategy of the World Bank in the 1990s. ${ }^{39}$ It remains a current issue - the need for more and better data collection is reiterated in the MDG Final Report in 2015. The observation, frequently found in the literature, that indicators are created largely by experts in the global North, but rely on data collection processes in the global South has a variety of further implications. ${ }^{40}$ What happens next 'when wealthy nation-states and international organizations try to impose quantitative regimes globally, (and) some nations find it difficult to comply' is both complex and unpredictable, as our case study of MDG 7D will illustrate. ${ }^{41}$

\footnotetext{
${ }^{37}$ Fukuda-Parr and Yamin (n 9) 61.

${ }^{38}$ Porter (n 10) 538. See also Bhuta (n 11); Davis et al., 'The Local-Global Life of Indicators: Law, Power and Resistance' in Merry et al. (eds) The Quiet Power of Indicators: Measuring Governance, Corruption and the Rule of Law (CUP 2015) 5 .

${ }^{39}$ For example, see Liam Clegg, 'Our Dream is a World Full of Poverty Indicators: The US, the World Bank, and the Power of Numbers' (2010) 15(4) New Political Economy 473 <http://doi.org/doi:10.1080/13563461003763170>. A renewed effort to collect poverty data from households was announced in $2015<$ http://www.worldbank.org/en/news/press-release/2015/10/15/worldbank-new-end-poverty-tool-surveys-in-poorest-countries $>$.

${ }^{40}$ Merry and Wood (n 11) 208.

${ }^{41}$ Espeland and Stevens (n 36) 411.
} 
Further, Espeland and Stevens observe that the work of measuring the world is intimately entangled with wider social and political processes: 'quantification usually is embedded in larger social projects.' ${ }^{42}$ The story we have offered in the preceding section of the co-emergence of the development project with a newly consolidating metric for measuring economic 'progress' in GNP is one illustration of this embedding, although we would resist an account which makes either the political project or the measurement project ontologically prior to the other. ${ }^{43}$ Taking an approach to the construction and circulation of development indicators that understands them as 'the work that makes other kinds of work possible' allows for analyses that trace the ways that particular indicators may function to advance, consolidate or confound larger political projects. As Amanda Perry-Kessaris observes of the World Bank's longstanding promotion of foreign direct investment as a development tool, by equating effective governance with its impact on perceptions of the 'climate for investment': 'Indicators are the weapons of choice for the knights of investment climate discourse.' ${ }^{44}$ Along similar lines, Tor Krever's account of the ways in which the World Bank's composite 'rule of law' indicator (under the auspices of its Worldwide Governance Indicators project) functions to reify a limited conception of lawfulness primarily identified with the protection of private property, contracts, and judicial independence reveal the extent to which this conception both fits within and serves to advance neoliberal global legal order. ${ }^{45}$

'Reactivity' is Espeland and Steven's second category; it is intended to direct attention to the ways in which measurement intervenes in the social worlds it purports to merely depict. Measures, in their account, are reactive in that they cause people to think and act differently. Sometimes these effects are intended, such as when governments seek to meet an MDG target for the education of girls by building more schools in poorer neighbourhoods, or even when a state might seek to improve its ranking in the World Bank's 'Doing Business' Index by reducing the time it takes to get a business license. Unintended consequences can and do arise in a variety of ways, either through actors seeking to 'game' the indicator, or through the re-allocation of resources to issues that are being tracked and away from equally

${ }^{42}$ Ibid.

${ }^{43}$ The idiom of 'co-production' is pertinent here, as a method which 'does not seek to foreclose competing explanations by laying claim to one dominant and all-powerful truth. It offers instead a new way of exploring the waters of human history, where politics, knowledge and intervention are continually in flux.' Jasanoff (n 1) 43.

${ }^{44}$ Perry-Kessaris, 'Prepare Your Indicators' (n 7) 402.

${ }^{45}$ Krever (n 7). 
significant but unquantified (or unquantifiable) issues. Espeland and Sauder explain that one common way for unintended consequences to arise is when changes in behaviour become 'decoupled from the processes the indicators are designed to reflect or measure'. ${ }^{46}$ Given the already observed tendency for the 'work' behind an indicator to fade into the background - it should not be surprising that development targets so often miss their mark.

The literature on development indicators is rich with illustrations of the unintended and potentially undesirable effects of measurement. The Millennium Development Goals in particular have been subject to many strong critiques along these lines. The 'Power of Numbers' project, directed by Yamin and Fukuda Parr, compiled case-studies on each of the Goals, all of which identified some form of unintended or undesirable effect. ${ }^{47}$ An often cited case in point is that of MDG\#2, the objective of which was to achieve universal primary education, where a number of critics have observed that poor countries were encouraged to focus limited resources on ensuring higher enrolment rates at the primary level. ${ }^{48}$ The spin-off, however, was that overall quality of education could suffer. Sufficient numbers of well-trained teachers were not necessarily available to take on the larger number of students, and where they were available, many faced dauntingly larger classrooms. Students might have been recorded as enrolled, but as the goal and its associated indicators did not incorporate a consideration of whether they become literate, or in many cases, whether they in fact ever finished primary education, it was difficult to see the link between the objective of improving

${ }^{46}$ Wendy Nelson Espeland and Michael Sauder, 'The Dynamism of Indicators' in Governance by Indicators: Global Power through Classification and Rankings, Kevin Davis et al. (eds) (OUP 2012) 92.

${ }^{47}$ Sakiko Fukuda-Parr et al., 'The Power of Numbers: A Critical Review of Millennium Development Goal Targets for Human Development and Human Rights' (2014) 15(2-3) J. Hum. Dev. Capab 105 <http://doi.org/doi:10.1080/19452829.2013.864622>. 'All (MDGs) led to unintended consequences in diverting attention from other important objectives and reshaping development thinking. Many of the indicators were poorly selected and contributed to distorting effects.'

${ }^{48}$ See, Ashwani Saith, 'From Universal Values to Millennium Development Goals: Lost in Translation' (2006) 37(6) Dev Change 1167 <http://doi.org/doi:10.1111/j.1467-7660.2006.00518.x>; Jeff Waage et al., 'The Millennium Development Goals: A Cross-Sectoral Analysis and Principles for Goal Setting after 2015' (2010) 376(9745) Lancet 991 <http://doi.org/doi:10.1016/S0140-6736(10)61196-8>; Amir Attaran, 'An Immeasurable Crisis? A Criticism of the Millennium Development Goals and Why They Cannot Be Measured' (2005) 2(10) PLoS Medicine e318 <http://doi.org/doi:10.1371/journal.pmed.0020318>. 
education and the metric of primary enrolments. ${ }^{49}$ As Saith succinctly sums up,

...focusing exclusively on indicators of educational enrolments has inherent distortions: it pays no attention to the very high drop-out rates in primary and secondary education in the developing economies; it ignores issues of quality of outcomes; and it is blind to the resources committed per child in the educational process. ${ }^{50}$

Ultimately, the targeting of primary education may have had the effect of drawing resources away from secondary and tertiary education sectors. ${ }^{51}$ This is an illustration of the ways in which successful indicators become powerful focal points for aligning expectations and influencing behaviour. ${ }^{52}$ Once they are produced and put into circulation, indicators can take on a 'life of their own', in which it is possible, even likely, that some or all of the uses to which they are put are 'foreign to the intentions of the original producers.' 53

Espeland and Stevens' third factor, which they call 'discipline', concerns the way in which quantification facilitates a certain type of governance. That is, numbers can circulate easily and appear straightforward to interpret, making it possible to monitor or govern 'at a distance'. ${ }^{4}$ This is made possible, largely, through the work of 'commensuration' - 'a process fundamental to measurement that entails turning qualities into quantities that share the same metric.' ${ }^{55}$ Development indicators (such as GNP) simplify, exclude, and integrate information, making it possible to track and compare the 'progress' of a diverse array of economies and nations. Commensurability between developing nations should be understood, however, as an effect or end product of a two-step process in which first, vast amounts of information are made irrelevant, and second, a shared metric is imposed upon what remains. ${ }^{56}$ Commensuration is instrumental to the way in which the

${ }^{49}$ Maya Fehling et al., 'Limitations of the Millennium Development Goals: A Literature Review' (2013) 8(10) Glob. Public Health 1115 <http:doi.org/doi:10.1080/17441692.2013.845676>; Angeline M Barrett, 'A Millennium Learning Goal for education post-2015: a question of outcomes or $\begin{array}{lllll}\text { processes' (2011) 47(1) Comparative Education } 119 & \end{array}$ <http:doi.org/doi:10.1080/03050068.2011.541682>.

${ }^{50}$ Saith (n 48) 1173.

${ }^{51}$ Waage et al. (n 48) 999.

${ }^{52}$ Davis et al., 'Introduction: Global Governance by Indicators' (n 34).

${ }^{53}$ Davis et al., 'The Local-Global Life of Indicators' (n 38) 15.

${ }^{54}$ Peter Miller and Nikola Rose, 'Governing Economic Life' (2006) 19(1) Econ Soc 1; James C Scott, Seeing Like a State: How Certain Schemes to Improve the Human Condition Have Failed (Yale University Press 1999).

${ }^{55}$ Espeland and Sauder, 'The Dynamism of Indicators' (n 46) 91.

${ }^{56}$ Wendy Nelson Espeland and Michael M Sauder, 'Rankings and Reactivity: How Public Measures Recreate Social Worlds' (2007) 113(1) Am. J. Sociol. 1. 
selection and tracking of indicators come to operate as mechanisms of governance through its ability to transform 'difference ...into magnitude... - a matter of more or less rather than of kind.' 57

Development indicators 'discipline' governments and institutions by making complex social and political choices and judgments seem straightforward, by enhancing the role of experts and the organizations that collect data at the expense of local knowledge and decision-making, and displacing political judgment and responsibility away from governing bodies.

Through the apparatus of science and measurement, the indicator displaces judgement from governing bodies onto the indicator itself, which establishes standards for judgement. Nevertheless, indicators are inevitably political, rooted in particular conceptions of problems and theories of responsibility. They represent the perspectives and frameworks of those who produce them, as well as their political and financial power. What gets counted depends on which groups and organisations can afford to count. ${ }^{58}$

The necessary simplification of quantification also makes information seem more authoritative. ${ }^{59}$ Not all quantitative measures have the same persuasive power, however; rather, the 'polyvalent authority' or legitimacy of a given measure is something that groups or institutions behind an indicator must work to secure. As Espeland and Stevens note, the acquisition and mobilization of quantitative authority is a complex social and institutional process, which 'gets built into institutions, circulates, and creates enduring structures that shape and constrain cognition and behavior.' ${ }^{60}$ One might point to the World Bank's measure of absolute poverty as one such authoritative development indicator that has shaped both cognition and behaviour (although not uncontroversially). ${ }^{61}$ Authority is not fixed or absolute, however. Rather, processes of authorization are ongoing and contested, as Liam Clegg's study of the complex struggles within and outside the Bank between income-based and multidimensional measures of poverty illustrates. ${ }^{62}$ Attending to the struggles through which the legitimacy of the poverty indicator is produced and contested is as revealing for what is left out as much as for what is being

\footnotetext{
${ }^{57}$ Espeland and Sauder, 'The Dynamism of Indicators' (n 46) 92.

58 Sally Engle Merry, 'Measuring the World: Indicators, Human Rights, and Global Governance’ (2011) 2(S3) Curr Anthropol S83, S88.

${ }^{59}$ Davis et al., 'Introduction: Global Governance by Indicators' (n 34) 17.

${ }^{60}$ Espeland and Stevens (n 36) 419.

${ }^{61}$ Maria Angélica Prada Uribe, 'The Quest for Measuring Development: The Role of the Indicator Bank ' in Merry et al. (eds) (n 38).

${ }^{62}$ Clegg (n 39).
} 
debated. ${ }^{63}$ In the case of poverty indicators, the available 'multidimensional' measures of poverty are also highly reductive. In the realm of development, one of the most widely recognized multidimensional development indicators, the Human Development Index, has been widely criticized on this point. ${ }^{64}$ One of the key authors of the Human Development Reports, Sakiko Fukuda Parr argues that the HDI only captures a small part of what would be considered important within a 'human development' framework, noting that 'ironically, the success of the HDI has only served to reinforce the narrow interpretation of human development. ${ }^{65}$ Another apparent paradox might be found here in an apparently inverse relation between the narrowness or reductivity of a particular metric, and its ability to be perceived and to circulate as legitimate and authoritative. Clarity and simplicity are essential if a new metric is to achieve a degree of recognition and credibility in the crowded and contested market of development indicators.

Goals use the power of numbers to communicate a development agenda with a sense of scientific certitude and serious intent with the potential for accountability. But, in reality, quantification reduces complex and intangible visions such as development that is inclusive into concrete and measurable objectives such as 'all children in school'. ${ }^{66}$

This brings us to Espeland and Stevens's final category, which seeks to draw our attention to the 'aesthetics' of how we make pictures with numbers, observing that we tend to value clarity and parsimony above other qualities in our visual information. In their account, these qualities manifest the particular allure of numbers noted above: their peculiar capacity to appear to make complex phenomena comprehensible. This last category has, arguably, become even more relevant to the work of the sociologist of quantification in recent years. In our current social media

\footnotetext{
${ }^{63}$ Robert Chambers, 'Poverty and Livelihoods: Whose Reality Counts?' (1995)

7(1) Environment and Urbanization 173 <http://doi.org/doi:10.1177/095624789500700106>.

${ }^{64}$ Stanton (n 31); Ambuj D Sagar and Adil Najam, 'The Human Development Index: A Critical Review' (1998) 25(3) Ecol. Econ 249 <http://doi.org/doi:10.1016/S0921-8009(97)00168-7>.

${ }^{65}$ Sakiko Fukuda-Parr, 'Rescuing the Human Development Concept from the Human Development Index: Reflections on a New Agenda' in Sakiko FukudaParr and A. K. Shiva Kumar (eds) Readings in Human Development: Concepts, Measures, and Policies for a Development Paradigm (OUP 2003) 117.

66 Sakiko Fukuda-Parr, 'From the Millennium Development Goals to the Sustainable Development Goals: Shifts in Purpose, Concept, and Politics of Global Goal Setting for Development' (2016) 24(1) Gend Dev. 43, 49 <http://doi.org/DOI: 10.1080/13552074.2016.1145895>.
} 
environment, the circulation of seductively appealing visualizations (infovis) of quantified information is rapid, widespread, and frequently detached from relevant interpretive context. ${ }^{67}$ Although development agencies have become increasingly sophisticated in their use of visual media to publicize various metrics in recent years, the role of aesthetics in the creation, circulation, legitimation, and influence of development indicators has, in our review of the literature, not yet been well studied. ${ }^{68}$

The visualization of data, along with the background work of determining what and how to count, the adaptations of those being counted (in our case, developing states), the legitimacy acquired by particular indicators and the disciplining or governance effects of metrics in circulation - each play a significant role in determining 'what gets done'.

D. Toward a sociology of the slum target: Millennium Development Goal 7. D

'Numbers often help constitute the things they measure by directing attention, persuading, and creating new categories for apprehending the world'. ${ }^{9}$

In this final section, and with the foregoing methodological roadmap in mind, we offer a brief account of the Millennium Development Goals process and the formulation, implementation, and dissemination of MDG 7.D in particular. Our account seeks to trace the widening ripples that result from the insertion of a new, quantified, target into the complex array of existing programs and policy relating to urban poverty, informal settlements, property, tenure, water, and sanitation already being advanced by global institutions including Cities Alliance, UN-Habitat and UNDP. This account is intended to be suggestive, rather than conclusive. That is, it is not our aim here to demonstrate the impacts of the

${ }^{67}$ Heather Houser, 'The Aesthetics of Environmental Visualizations: More than Information Ecstasy?' (2014) 26(2) Publ. Cult 319 <http://doi.org/doi:10.1215/08992363-2392084>.

${ }^{68}$ But see Perry-Kessaris, 'The Case for a Visualized Economic Sociology' (n 16). The approach I am arguing for here is distinct from the case argued by Perry-Kessaris in that I am calling for an engagement with the 'aesthetics' of quantified development indicators more generally, in a manner which would incorporate a wide range of visual media, including but extending beyond graphic design. Further, following Espeland and Stevens's lead, incorporating the visual dimension into a sociology of development indicators could entail the consideration of the relationship between different forms of quantitative analysis and their representation or attending to the constitutive role of a particular 'aesthetic' in the construction of a particular indicator.

${ }^{69}$ Espeland and Stevens (n 36) 404. 
slum target, but rather, to illustrate how, through (re)framing our orientation to the study of the target, that the question of its effects presents itself as legitimate terrain for future research.

The disconnect between the aspirations expressed in the Millennium Declaration - that it would inaugurate an era of people-centered development policies, guided by a human development framework and respectful of human rights - and the Millennium Development Goals process that followed has been widely commented on. ${ }^{70}$ Yet our analysis suggests that it is how we characterize the social processes which unfolded in that space that matters: was it merely a process of translation, of information gathering for the purpose of policy making and increased accountability, or a globalized imposition of categories with consequences on poor countries?

While a detailed, sociologically oriented history of the process by which a group of objectives became identified in the Declaration and were eventually 'translated' into 8 goals, 21 targets and 60 indicators is well beyond the scope of this chapter, it is important to make note of a few key milestones in the MDG process as a whole in order to make sense of our account of the evolution and application of MDG 7.D. ${ }^{71}$ The targets that became the MDGs find their roots in geopolitics and development discourses that preceded them. The end of the Cold War reduced the East-West paralysis between Western and USSR-aligned blocs at the United Nations. ${ }^{72}$ While the human development approach took hold through the 1990s, and within that the Human Development Index (HDI), several international summits and conferences proved foundational to the later articulated MDGs. The earliest was that of the International World Summit for Children in 1990, followed by the International Conference on Population and Development (ICPD) in September 1994, and both the Fourth World Conference on Women in Beijing and the Summit for Social Development in Copenhagen 1995. The Social Summit in particular was 'crucial for the MDGs as global

${ }^{70}$ David Hulme and Sakiko Fukuda-Parr, 'International Norm Dynamics and 'the End of Poverty': Understanding the Millennium Development Goals (MDGs)' (2009) 96 Brooks World Poverty Institute Working Paper <https://ideas.repec.org/p/bwp/bwppap/9609.html>; Fukuda-Parr, 'The Power of Numbers' (n 47).

${ }^{71}$ David Hulme, 'Lessons from the Making of the MDGs: Human Development Meets Results-based Management in an Unfair World' (2010) 41(1) IDS Bulletin $15<$ http://www.ids.ac.uk/publication/the-mdgs-and-beyond>; Saith (n 48); see also Hulme and Fukuda-Parr ibid.

72 Jan Vandemoortele, 'If not the Millennium Development Goals, the what?' (2011) 32(1) Third World Q. 9. Vandemoortele suggests that 'some observers now see them as the apotheosis of the multilateralism of a bygone era.' 16. 
consensus was reached that poverty eradication was the priority for development,' (as originally emphasised). ${ }^{73}$

Around this time, the OECD's Development Assistance Committee established a Groupe de Réflexion to examine all the declarations and concluding resolutions from the UN summits in the early 1990s. In May 1996, the Groupe published their first paper in which they set out six quantitative 'International Development Goals' (IDGs). Like the later MDGs, the IDGs were concerned with issues of poverty, education, and health and set a deadline of 2015 for achievement. Although the goals were initially given limited attention, they slowly gained more traction as the Millennium Summit drew near. ${ }^{74}$

In March 2000, the UN released a report entitled We the Peoples: The Role of the United Nations in the $21^{\text {st }}$ Century, which re-visioned the UN's role in development. Among other things, the report declared 'a more people-oriented United Nations must be a more results-based organization,' (as originally emphasised). ${ }^{75}$ As would be seen, the We the Peoples report captured many of the themes that would later form the Millennium Declaration. Like the OECD-DAC's IDGs, it drew together resolutions from the UN conferences of the 1990s, but on a broader range of topics. ${ }^{76}$

In September 2000, 189 countries signed the Millennium Declaration. To avoid having the unprecedented international commitment slip into obscurity, the UN quickly set about creating tangible goals around which to anchor the promises made in the Declaration. A group was soon established to translate the Declaration into a list of targets and indicators. Interestingly, this was the same group ${ }^{77}$ that had worked together to create the list of IDGs released jointly by the UN, OECD, World Bank, and IMF report in October 2000, one month following the signing of the Declaration. ${ }^{78}$

\footnotetext{
${ }^{73}$ Ibid.; see also Saith (n 48). For more historical context of the MDGS, see Hulme (n 71).

${ }^{74}$ Kate Higgins, 'Reflecting on the MDGs and Making Sense of the Post-2015 Development Agenda' Research report (North-South Institute (NSI) 2013) 2.

${ }^{75}$ Kofi A Annan, We the Peoples: A UN for the Twenty-First Century (United Nations 2000) 73.

76 David Hulme, 'The Millennium Development Goals (MDGs): A Short History of the World's Biggest Promise' (2009) 100 Brooks World Poverty Institute Working Paper 26 <http://www.ssrn.com/abstract=1544271>.

${ }^{77}$ Hulme and Fukuda-Parr 'International Norm Dynamics' (n 70) 16. According to Hulme \& Fukuda-Parr, the ad hoc group consisted of the World Bank's Eric Swanson, OECD-DAC's Brian Hammond, and the UNDP's Jan Vandemoortele. See also Sakiko Fukuda-Parr, 'Global Goals as a Policy Tool: Intended and Unintended Consequences' (2014) 15(2-3) J. Hum. Dev. Capab 118, 128.

${ }^{78}$ Hulme 'The Millennium Development Goals (MDGs)' (n 76) 18. See also the IMF, OECD, UN \& World Bank report: A Better World for All (International Monetary Fund, Organization for Economic Cooperation and Development,
} 
After the passage of the Millennium Declaration, there was a perceived need to avoid duplication of global efforts, and the IDGs presented an attractive and convincing model around which to mobilize support. Efforts were then taken to transform the IDGs from donor goals to global goals. ${ }^{79}$ It was no easy feat, as Karver, Kenny and Sumner noted, since the MDG creators had to walk a 'tightrope' between the ambitious targets that had been agreed to in prior UN summits and conferences, and targets that were politically palatable and therefore fell within the realm of possibility. ${ }^{80}$

The eight MDGs were officially revealed on 6 September 2001 through the Road map towards the implementation of the United Nations Millennium Declaration: Report of the Secretary General. ${ }^{81}$ Of the seven key objectives listed in the Millennium Declaration, only one became fundamental to the MDG framework - that of development and poverty eradication. ${ }^{82}$ Others, such as those relating to peace, security, disarmament, human rights and democracy, were left behind. Hayman argued that such limits made it easier for donors to justify policies that focused solely on MDG targets. ${ }^{83}$

The resulting MDG goals were originally set out as global goals, however there was soon pressure for those same goals to be taken on as country targets. The problem with this was that global goals were set outside of any consideration of particular countries historical experiences and thus each goal was not necessarily attainable at the country level by every country. ${ }^{84}$

To the extent that the list of goals was based largely on goals previously created by the OECD, World Bank, and IMF together with the UN, and were operationalized by a small group of development 'experts' located in the north, the MDG process

United Nations, and World Bank, 2000). See also Table 1 in Hulme 'The Millennium Development Goals (MDGs)' (n 76) 15 for a comparison of the IDGs and MDGs.

${ }^{79}$ Sakiko Fukuda-Parr, 'Theory and Policy in International Development: Human Development and Capability Approach and the Millennium Development Goals' (2011) 13(1) Int. Stud. Rev 122, 127.

${ }^{80}$ Jonathan Karver et al., 'MDGs 2.0: What Goals, Targets, and Timeframe?' Working Paper No 297 (Center for Global Development, 2013) 18 <https://www.cgdev.org/publication/mdgs-20-what-goals-targets-andtimeframe-working-paper-297>.

${ }^{81}$ Kofi A Annan, 'Road map towards the implementation of the United Nations Millennium Declaration: Report of the Secretary General' UN General Assembly A/56/326 (United Nations, 2001).

${ }^{82}$ Maya Fehling (n 49) 1113.

${ }^{83}$ Rachel Hayman, 'Are the MDGs Enough? Donor perspectives and recipient visions of education and poverty reduction in Rwanda' (2007) 27(4) Int J Educ Dev 371 in ibid. at 1114.

${ }^{84}$ Jonathan Karver et al. (n 80) 18-19. 
can be understood as an extension and elaboration of the 'development project' described at the outset of this chapter. This dynamic led some to argue that the MDG concentration on developing country issues serves to 'ghettoize the problem of development and [locate] it firmly in the third world.' ${ }^{85}$ And yet, once the contested process of framing, selecting, and defining was completed, the MDG targets were presented to the world not as political, but as technical problems, ${ }^{86}$ illuminating as discussed above one of the ways in which quantification operates to obscure its social embeddedness. At the global level, the MDGs operated as a powerful vehicle for the production of knowledge about poorer nations, re-'making' the world in ways that Truman would have found familiar, with ongoing, albeit unacknowledged, consequences. The development project is at this point so thoroughly embedded within the common sense of international institutions that it can be difficult to envision alternatives at the macro-level. The implications of particular practices of measurement can more readily be grasped in the moment of intervention or imposition of particular new measurements or targets, such as in the case of MDG Target 7D.

MDG 7D was drawn from the inaugural report of an umbrella organization called Cities Alliance, a partnership between the World Bank, UN-Habitat, and a small handful of governments and nongovernmental organizations, formed in the late 1990s. Cities Alliance launched the 'Cities without Slums Action Plan 'at its inaugural 1999 meeting. ${ }^{87}$ The Plan found new form as Millennium Development Goal 7, target 11, later revised as Millennium Development Goal 7D. The Millennium Declaration of September 2000 explicitly recognized this link: 'By 2020, to have achieved a significant improvement in the lives of at least 100 million slum dwellers as proposed in the 'Cities Without Slums' initiative.' ${ }^{88}$ It is important to note that at the time of the Millennium Declaration, no universally accepted definition for the term 'slum' existed. Indeed, in the decades prior, countries had rarely included data on slums in their development reports. ${ }^{89}$ Given that the objective of the Millennium Declaration was to

\footnotetext{
${ }^{85}$ Saith (n 48) 1184.

${ }^{86}$ Kennedy (n 6) 29-31.

${ }^{87}$ Cities without Slums Action Plan <http://www.citiesalliance.org/cws-actionplan>.

${ }^{88}$ United Nations Millennium Declaration, 55/2. 8th plenary meeting, 8 September 2000, Part $\quad$ III, $\quad 19$ < http://www.un.org/millennium/declaration/ares552e.htm>.

${ }^{89}$ Gora Mboup, 'MDG Goal 7 Target 7D (Target 11) - Slum Target' (Presentation delivered at the UN Habitat City Census Workshop, September 27-29 2010) Economic and Social Commission for Western Asia < http://css.escwa.org.lb/sd/1342/1_3.pdf>.
} 
'mainstream a set of inter-connected and mutually reinforcing development goals into a global agenda,' it followed that the inclusion of a 'slum' target in the universalized MDG project would require a universal definition for this complex phenomenon. ${ }^{90}$ In identifying 'slums' as a problem for cities that aspired to be modern, the Cities Alliance initiative and the ensuing MDG process called for the creation of a new area of knowledge and expertise. Unsurprisingly, the work of defining, tracking and targeting this new global entity of the 'slum' fell to a small group of already identified global development 'experts'.

In October 2002, thirty-five international experts joined Cities Alliance and UN Habitat staff in Nairobi to formulate 'an operational definition of security of tenure and slums" ${ }^{\prime 91}$ over two days. They produced a series of 'sub-indicators' to measure both security of tenure and slums, as well as 'composite indices and meta-indicators. ${ }^{, 92}$ While it was recognized that the definitions and indicators agreed upon would continue to be modified, this small group of people ostensibly succeeded in casting a universal definition of what it meant to live in a slum. A slum household was defined as 'a group of individuals living under the same roof that lack one or more of: access to improved water; access to improved sanitation; durability of housing; security of tenure; [and/or] sufficient living area'. ${ }^{93}$

As we've discussed in the previous section, the background 'work' of constructing an indicator involves often difficult and contentious selections of emphasis - some elements are highlighted at the expense of others. However, there is often a certain inevitability, or path dependency, associated with the process of narrowing that accompanies the identification of data points that can be tracked. Statistics that are already being gathered tend to be selected; elements for which no current data exists will be dropped. Not surprisingly, the most difficult element of the slum definition the experts in Nairobi discussed measuring was security of tenure. The group defined security of tenure as 'the right of all individuals and groups to effective protection from the

\footnotetext{
${ }^{90}$ Expert Group Meeting on Urban Indicators, 'Secure Tenure, Slums and Global Sample of Cities' (UN-HABITAT, Urban Secretariat and Shelter Branch 2002) 4 <http://www.citiesalliance.org/sites/citiesalliance.org/files/expertgroup-meeting-urban-indicators\%5B1\%5D.pdf $>$.

91 Ibid. 3.

92 Ibid. Unsurprisingly, from the outset the task of defining slums was politically fraught: 'Participants sought clarity on the operational definitions of indicators and by doing so, underscored the political dimension of tenure and slums, and reasserted the need for a rights-based approach improving the lives of 100 million slum dwellers.'

93 Ibid.
} 
state against unlawful evictions.' ${ }^{94}$ This definition reflects the concern that security of tenure be defined in a way that addressed the problems associated with its absence. While ultimately security of tenure remained included in the universal definition of slum noted above, unlike all other elements of the definition, indicators for the concept were left to be 'defined later'.

The 'slum' definition and indicators that came out of the Nairobi meeting in 2003 continued to evolve, as elements of slums that could be most amenable to measurement were foregrounded and more problematic elements were cast away. Security of tenure would ultimately prove too difficult to measure and be removed from the slum definition, notwithstanding clear evidence that it was central to urban development and protection from forced evictions and other human rights violations. A 2006 UNEP report on MDG progress called it a particularly difficult indicator to measure, but at the same time 'one of the most essential elements of a successful shelter strategy.' 95

While the original MDG targets and framework were reportedly settled in $2003,{ }^{96}$ the importance of security of tenure became less recognized over time as the measurability of the indicator remained in question, and targets and indicators for the other 'elements' of the slum definition were solidified, tracked and recorded. The 2005 World Summit led the UN Secretary General to recommend the addition of four new MDG targets (A, B, C and D). In 2007, the UN General Assembly agreed to include these four additional targets and re-organize the MDG, reframing the slum target from Goal 7, Target 11 to MDG Target 7D. This new official framework 'supersede[d] the previous version,' 97 effectively excluding security of tenure from the MDG slum definition and MDG discourse, with little explanation or notice. The UN Statistics division concisely notes the outcome of this culling process in a footnote: '...since information on secure tenure is not available for most of the countries, only the first four indicators are used to define slum household, and then to estimate the proportion of urban population living in slums'. ${ }^{98}$

Security of tenure did not disappear altogether in development discourse and programming, but its prominence,

\footnotetext{
94 Ibid. 8.

95 Millennium Development Goal 7: Ensure Environmental Sustainability (Report compiled by UNEP and UN-HABITAT 2006) 14.

96 Millennium Development Goals

<https://mdgs.un.org/unsd/mdg/Metadata.aspx?IndicatorId=32>.

97 The World Bank Group, Millennium Development Goals <http://web.worldbank.org/archive/website01058/WEB/GDMIS122.HTM?siteI $\mathrm{d}=2 \&$ menuId=LNAV01 $>$.

98 Millennium Development Goals Indicators, Series Metadata <https://mdgs.un.org/unsd/mdg/Metadata.aspx>.
} 
legitimacy, and funding were dramatically impacted. Tenure security was relegated to a separate 'track' through the UN Habitat's Global Campaign for Secure Tenure. Even as MDG programming continued apace and MDG progress reports repeatedly cast security of tenure as too difficult to measure, the UN Special Rapporteur on the Right to Housing convened its [his] own expert working groups on indicators for the right to housing, including secure tenure. This schism presents one intriguing avenue for future research. Interviews with participants in the discussions that took place within UN and intergovernmental institutions and at past expert meetings where the slum target was formulated and operationalized might reveal tensions between rights talk and efficiency-oriented approaches to growth jostling for prominence. ${ }^{99}$ Reconstructing the debates among experts could reveal the political stakes of different methods and modes of quantification that remain opaque in the ensuing data. What can be noted without access to these insights, however, is that the element of tenure security calls for recognition of the right to land use and occupation by the poor, situating their rights vis-à-vis others - a relative, rather than an absolute, approach to poverty and poverty alleviation that problematizes and politicizes land inequality in cities in a way that improved water and sanitation campaigns do not.

In what was perhaps an effort to avoid politics, the excision of security of tenure from the MDG slum target was a political choice itself. Seemingly based on exigencies of measurement and the political volatility of the tenure indicator, rather than other factors that might arguably be more closely linked to the goal of bringing about 'improvements' in living conditions of the urban poor, it was a decision that had significant effects not only on the production of knowledge about slums and slum residents, but also on the ways in which governments acted to achieve the targets. ${ }^{100}$ We don't want to be read as suggesting that a better decision would have been to include - and therefore, find a way to quantify - the right to tenure security. Rather, our claim is a more basic one about the entangled relationship between defining and measuring. Our argument is that in relation to the MDG Target 7.D, as with the various other development indicators we've discussed in this chapter, it is in the process of 'making the myriad decisions

99 The Challenge of Slums: Global Report on Human Settlements (UNHABITAT 2003).

${ }^{100}$ Marie Huchzermeyer provides an excellent critical account of the effects of MDG 7D in several African nations. In particular, she traces the ways in which governments in South Africa, Zimbabwe and Nigeria made reference to the target in justifying the necessity of various slum eradication projects. Marie Huchzermeyer, Cities with 'Slums' from Informal Settlement Eradication to a Right to the City in Africa (UCT Press, 2011). 
necessary to operationalize a (legal) definition,' such as UN Habitat's definition of a 'slum', that the phenomenon itself is produced. ${ }^{101}$

\section{E. Conclusion}

Perhaps targeting a problem is not always as useful as situating a problem. Perhaps it encourages us to focus on symptoms rather than causes; perhaps it leaves unaddressed, and hence intact, the many direct and indirect sources of the problem that we seek to solve or alleviate. ${ }^{102}$

Though the debates over methodology and measurement in relation to development outcomes are both convoluted and contentious, the technocratic nature of the development project as it emerged in the postwar moment remains a constant. Insofar as the project of international 'development' was conceived fundamentally as a project of (economic) measurement, comparison and quantification, the indicators and statistics in use at a given time provide determinate content to the aspirational project of development. Development indicators frame both objects and outcomes through a transformative lens which conflates means and ends; equating the collection of ever more quantifiable and globally commensurable data points with the project of realizing stated ambitions of global development institutions, as exemplified by the World Bank's own slogan 'Our Dream is a World Free of Poverty'.

From the postwar prominence of GNP to the Millennium Development Goals, the perspective taken by the 'development project' has been a high level 'view from above' which presumes that we can 'see' a national economy as a totality and measure its successes and failures in aggregative terms and moreover, that

101 A similar argument is made by Kerry Rittich in the context of trafficking and forced labour in 'Representing, Counting, Valuing: Managing Definitional Uncertainty in the Law of Trafficking" (2017) P. Kotiswaran, ed Revisiting the Law and Governance of Trafficking, Forced Labour and Modern Slavery (Cambridge U Press). 'In addition, the exercises in defining, measuring and valuing reveal trafficking and forced labour to be not simply problems that we struggle to regulate and repress through legal rules and regimes. Instead, they appear to possess a prior, more intimate relationship to law. We might say, then, that it is in the process of making the myriad decisions necessary to operationalize the legal definitions of trafficking and forced labour by which - in theory - we merely seek to capture and control them that the phenomenon of trafficking is itself produced.'.at p. 270.

${ }^{102}$ Kerry Rittich, 'Governing by Measuring: The Millennium Development Goals in Global Governance,' in Ruth Buchanan and Peer Zumbansen (eds), Law in Transition: Human Rights, Development and Transitional Justice (Hart Publishing, 2014) 184. 
those statistics can be usefully compared with those of other 'national economies'. In this chapter, we have explored the process by which the 'power of numbers' operates within development discourse. In particular, we have sought to reveal something of the process, or 'work', through which these difficult and contestable choices about what issues to give priority to and which data to track, become 'black-boxed' in the ensuing indicator, such that the resulting 'data' appear straightforward and 'factual'. We have also explored the ways in which some topics come to seem both evidently priorities and inherently 'measurable' (income poverty) while other issues remain stubbornly beyond the reach of both statistical indices and public attention. Drawing on the robust body of recent scholarship on development indicators, we have illustrated the ways in which these metrics tend to remake the world they are purporting only to reflect; the governance implications of the production of quantitative data that is globally commensurate; and the ways in which indicators make claims to authority. We have also noted the related and growing significance of the production and circulation of visualizations of quantitative information such as development indicators.

We have suggested ways that the complex social process that unfolded between the articulation of lofty global aspirations in the Millennium Declaration and the searchable set of data points, data visualizations and reports that emerged from the MDGs in 2015 might be studied and understood as a constitutive process, a type of world-making with profound consequences for poorer countries. Our short history of MDG 7.D in the final section of the chapter sought to illuminate some of the particularities of its production and operationalization, the configuration of the relations between the 'technical' and the 'political' in the definition and measurement of slums, and to suggest how that process contributes to re-defining the appropriate nature and scope of development policy in urban contexts. We argue that the operationalization of the MDG 7.D target effectively reduced a complex and diverse field of urban development planning and policy to a narrow (and politically contentious) definition of the 'slum' buttressed by a very limited number of quantifiable indicators. In the context of the global profile of the MDGs, the aggregate of these quantifiable indicators came to determine which neighbourhoods counted as 'slums', notwithstanding the heterogeneity of built environments and populations residing in urban settlements around the world. Moreover, the coalesced support of international institutions for the MDGs lent a considerable amount of momentum to the City without Slums target and its partial and reductive set of indicators, potentially overriding more complex analyses and policy recommendations 
regarding the diverse circumstances of the marginally housed urban poor. The way in which this target was operationalized, and in particular the decision not to track security of tenure, an element that could have revealed pertinent differences in the ways in which different jurisdictions sought to improve their statistics on the indicator, is a poignant illustration of the necessary corollary to the MDG slogan 'what gets measured gets done.' In the realm of quantified knowledge production for development, it might equally be claimed: 'what doesn't get measured, doesn't count'. 